\title{
HYDROLOGICAL INVESTIGATION OF SOILS IN RELATION TO GULLY HEAD DEVELOPMENT IN SOUTH EAST SPAIN
}

\author{
Carolyn Francis*
}

\begin{abstract}
RESUMEN
Medir el crecimiento de gullies en diferente litologías, el método de trabajo y líneas de investigación son basados en el ciclo hidrológico sobre las vertientes. Varias técnicas de campo y laboratorio (normal y no normal) son usadas para describir la condición hidrológica, las características de los suelos y vegetaciones.
\end{abstract}

\section{SUMMARY}

To examine gully growth in different lithologies the methodology and choice of variables are based on the hillslope hydrological cycle. A number of standard and non standard field and laboratory techniques are used to describe the hillslope hydrology, soils and vegetation.

Gullies are erosional features principally by the action of flowing water. Theoretical work on hollow extension has concentrated on surface discharge and slope variables as the main causes of erosion (SMITH and BRETHERTON 1972, and KIRKBY 1980). Field work has also isolated processes and soil parameters affecting gully growth (IRELAND et al 1939, BRICE 1966, PIEST and Bowie 1974, and IMESON et al 1982). However there seems to have been little monitoring of the hydrology of slopes above gully heads.

The aim of this project is to assess the importance of surface and subsurface flow to gully growth by monitoring the hydrological properties of the slope as well as measuring some edaphic and vegetal characteristics.

* Department of Geography, Bedford College, Regent's Park, London, NW1. 4NS. 


\section{CAROLYN FRANCIS}

\section{LINE OF INVESTIGATION}

\section{Basis For Sampling}

The choice of variables for study was based on the main sections of the hillslope hydrological cycle, namely precipitation, infiltration, surface flow, and subsurface flow. Infiltration values can be used to estimate the proportion of precipitation entering the soil, and flowing over the surface. The quantity of surface wash reaching the gully head for different storm sizes and antecedent conditions can be modelled. Values for sediment transport allow comparison of the erodibility of different lithologies, location of erosion and deposition, and estimates of sediment entering the gully itself.

The importance of throughflow to gully head extension can be assessed for different antecedent soil moisture conditions by solving Darcy's Law for flow through the soil:

$$
\mathrm{q}(\text { saturated })=\mathrm{K} .(\partial \varphi / \partial \mathrm{L}) \text { and } \mathrm{q}(\text { unsaturated })=\mathrm{K}(\theta) .(\partial \varphi / \partial \mathrm{L})
$$

where $\mathrm{K}$ is the hydraulic conductivity, $\theta$ indicates moisture dependence, $\theta$ is the hydraulic head, and L is the length. For the saturated case the parameters can be obtained readily, but estimation of flows for unsaturated conditions requires the characteristic curve between soil moisture and soil tension (CAMPBELL 1974). This analysis assumes no macro flow in pipes through the soil.

Other useful data includes the effect of vegetation on surface and subsurface flow, and physical and chemical soil properties such as particle size, and $\mathrm{CaCO}_{3}$ values.

\section{Choice of Study Area}

The best place to study gullies are areas where they develop free from constraints into 'typica' forms. Here the dominant variables affecting gully growth should be most readily isolated. Such areas can have low threshold values and be sensitive to change (CAMPBELL and HONSAKER 1982) so that the relationship between modern processes can be good. However WISE et al (1982) point to fresh-looking gully forms over 4000 years old.

Gully erosion is most common in semi arid areas where gullies do develop into spectacular badlands. Low volume, high intensity precipitation falling seasonally and high evapotranspiration rates are effective in inhibiting vegetation and, together with poorly consolidated soils and steep slopes, cause high runoff rates and erosion.

Much of south east Spain exhibits these factors, and large tracts of badlands occur for example near Tabernas, and in the Guadix basin. The Ugijar basin is extensively eroded, although badlands have not fully developed, and a site near Ugijar, Province of Granada, was chosen for the study 
Figure 1. Study Site.

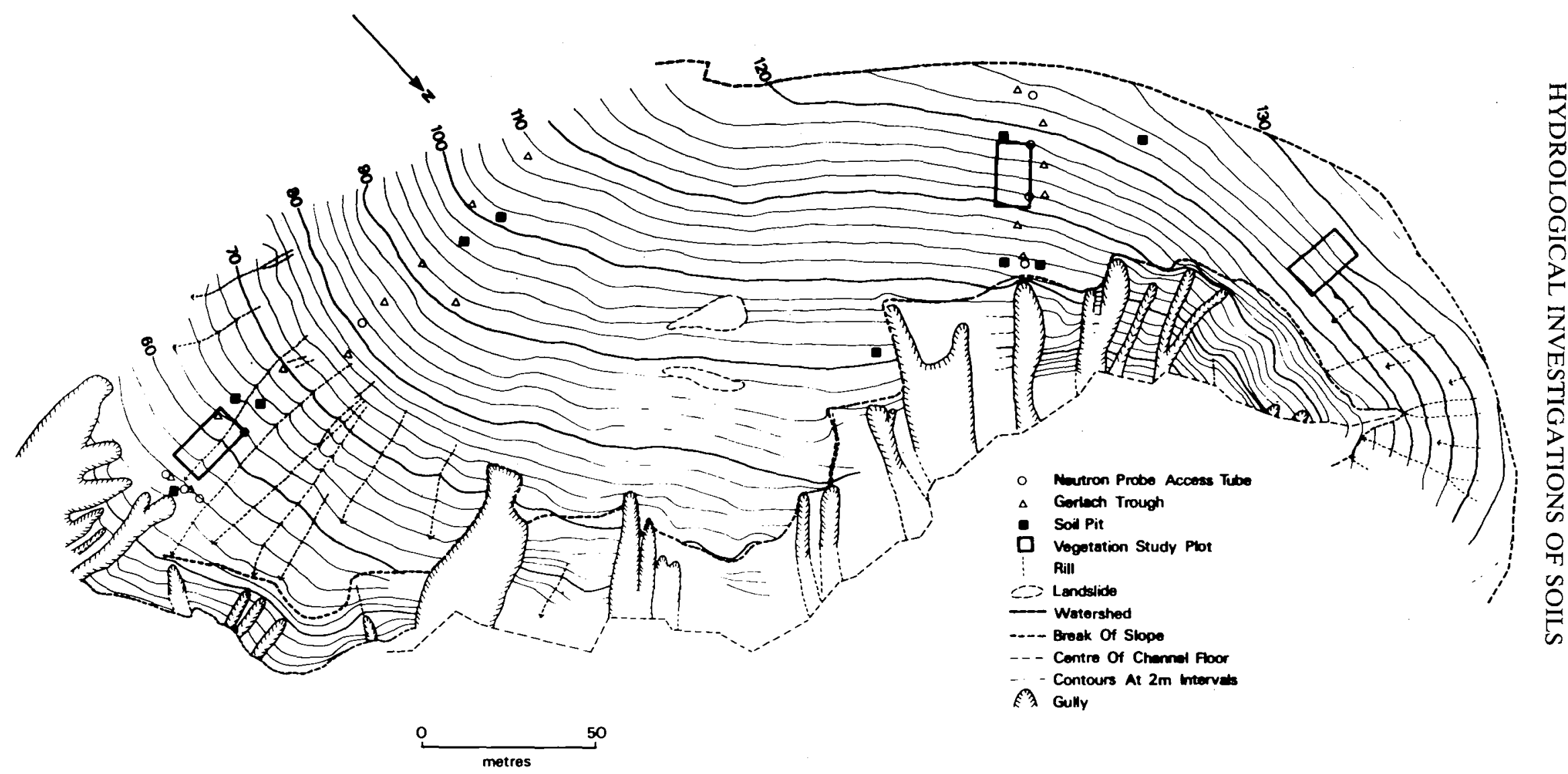


(figures 1 and 2). The geology and some processes have been described elsewhere for this area (THORNES 1976 and SCOGING 1982).

\section{Choice Of Site}

Two sites were chosen with different lithologies to compare soil erodibility and susceptibility to gully erosion. Both sites were chosen with several factors in mind, not all of which could be met.

Firstly the lithologies examined had to be known to be susceptible to extensive gully erosion. In the Ugijar basin aerial photography and ground reconnaissance showed that both the red Tertiary/Quaternary conglomerates and marls were gullied. Elsewhere in Spain the marls have formed badlands. The actual site only needed 1 or 2 isolated small or incipient gullies with well defined catchment areas. In badlands competing gullies have very small catchment areas and the subsurface hydrology is complicated (FAULKENER 1974).

Secondly the sites needed to be as simple as possible to reduce the number of variables affecting gully growth. This includes having simple lithologies, geological structures and slope forms, with no piping or channelled surface flow. Site 1 lies on a spur with a slight depression towards the base. Most of the slope is on marl, but the upper quarter is covered by the red conglomerate. The lower section does have rills which will complicate the distribution of surface and subsurface flow. These were not accounted for in the instrumentation. Site 2 is convex in the downslope direction, but uniform across slope. The bedrock is marl but this is covered by at least $1 \mathrm{~m}$ of red soil, and the hydrological processes are effectively occurring in the red soil.

Thirdly the sites would ideally be uncultivated and unvegetated. Cultivation disturbs the soil and alters sediment yields, whilst vegetation interferes with the processes of erosion. However in this area uncultivated land is covered with matorral. On the sites chosen there was no evidence of recent cultivation and the vegetation cover was sparse.

The layout of the sampling and monitoring positions follows the main flowlines into the gully heads (figure 1).

\section{Timing Of Field Work}

Three field excursions were undertaken to monitor conditions during different times of the year in July 1982, November-December 1982, and April-May 1983. The July field session was to monitor the drought conditions of the hot dry summer. The other two excursions were to monitor the effects of storms on the hillslope. The Easter trip was also to illustrate the downdraw of soil moisture with increasig aridity as summer commenced. 
HYDROLOGICAL INVESTIGATIONS OF SOILS

Figure 2. Location of Study Site.

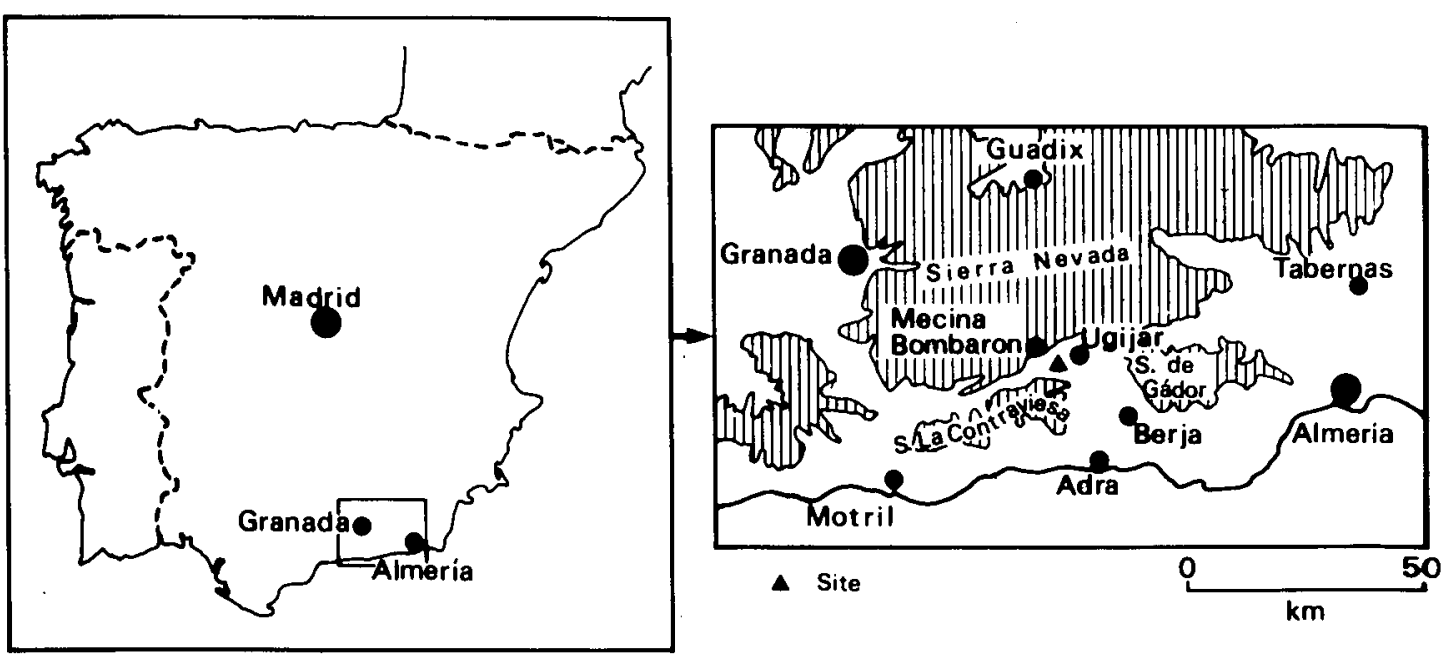

1. Variation of soil moisture with depth on three different dates
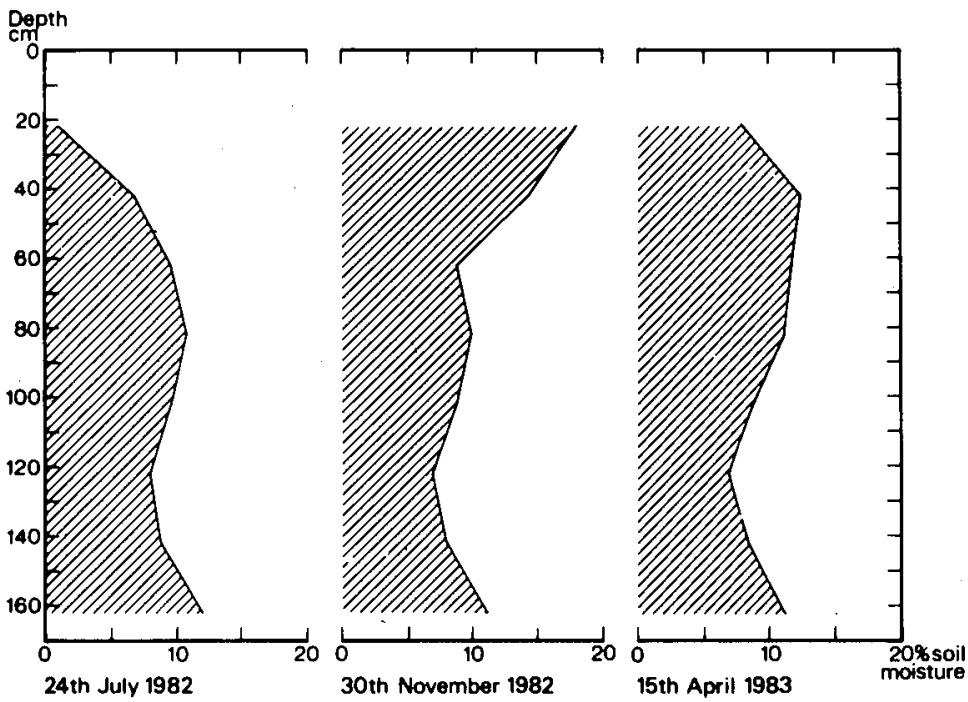

2. Variation of soil moisture at $42 \mathrm{~cm}$ depth with time
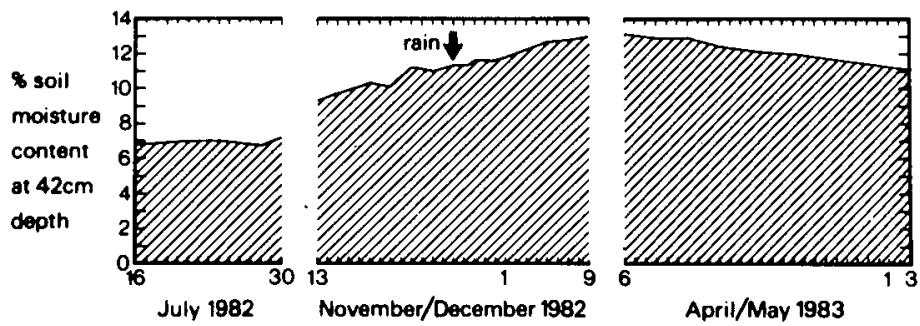

Figure 3. 


\section{CAROLYN FRANCIS}

\section{VARIABLES AND TECHNIQUES}

Data was collected by field instrumentation and laboratory analysis on a spatial and temporal framework using a mixture of standard and non-standard techniques.

Precipitation data for 1980-4 was obtained from the Hidrological Confederation Aguas Del Sur, Malaga for the stations at Ugijar and Mecina Bombaron $(4.5 \mathrm{~km}$ and $9 \mathrm{~km}$ from the site respectively). The mean annual precipitation for Ujigar for a 9-year period prior to 1976 was $412 \mathrm{~mm}$ (SCOGING 1976) but for the study period October 1982 to September 1983 the total rainfall was $205.7 \mathrm{~mm}$. The study occurred during a sequence of dry years (SALES MARTINEZ et al, 1982) which would have affected the range of some of the hydrological results.

Infiltration characteristics were measured for both sites using a drip feed, constant head infiltrometer (HILLS, 1970), and the results were analysed after WISE et al (1982).

Soil surface and runoff characteristics including 1. vegetation cover, 2 . analysis of soil surface material, and 3. sediment yield and runoff quantities were measured. Vegetation cover was mapped at the small scale $(20 \mathrm{~m} \times 10 \mathrm{~m}$ plots) and large scale $(1.5 \mathrm{~m} \times 0.5 \mathrm{~m}$ erosion plots) using tapes and quadrats. The amount of bare ground for both sites ranged betwen $40-80 \%$. Soil samples were collected using Kubiena tins and analysed for soil moisture content thermogravimetrically and organic litter content by ignition loss tests (BLACK 1965).

Overland flow and sediment from erosion plots $\left(1.5 \mathrm{~m}^{2}\right)$ was caught by Gerlach troughs with 10 troughs on site 1 , and 6 on site 2 . The troughs were carefully positioned to minimis disturbance to the soil, with the upslope end set in a thin layer of cement to anchor it and allow a smooth transition from the soil surface. Stone and cement walls bounded the upper end of the erosion plots.

Soil profiles from pits up to $1.4 \mathrm{~m}$ deep were described using the Soil Survey Field Handbook (ed. HODGSON, 1976). Undisturbed cores were analysed for soil moisture content, bulk density, and $\mathrm{CaCO}_{3}$ content (BLACK, 1965).

Subsurface variations in soil moisture with depth, location and time were measured using a Wallingford neutron probe following the Users Handbood (INSTITUTE OF HYDROLOGY, 1981). The readings were calibrated by thermogravimetric determination of soil moisture to give the volume of water per volume of soil.

Three soil monoliths approximately $30 \mathrm{cms}^{3}$ (two marl and one red soil) were cut out of the ground and coated in a mixture of resin and fibre glass. The marl can maintain vertical sides when it is dry and good samples were 


\section{HYDROLOGICAL INVESTIGATIONS OF SOILS}

taken. The red soil however was more friable and the samples were poorer. These soil monoliths were cut up into smaller blocks in the laboratory using a diamond saw and used to measure values for saturated hydraulic conductivity and obtain the soil moisture retention curves for the soils using a pressure chamber apparatus. Soil tension was also measured in the field, but for most of the year soil tensions were too high to be measured by tensiometers.

\section{RESULTS}

Although experimentation and analysis is still underway, preliminary results are available describing some of the variation and magnitude of gully forming processes. Presented here are some soil moisture data.

Figure 3 shows some values for soil moisture in the marl above the gully head for different depths and times. These show that below c60cms there is little seasonal variation in soil moisture. The greatest effects of evaporation and rainfall occur within the top $50 \mathrm{cms}$ (figure 3.1). In these upper layers soil moisture varies seasonally and is low and stable for the summer, increases with rainfall in the autumn, and decreases with the onset of the summer drought (figure 3.2). This suggests that throughflow is small and limited to the uppermost horizons in marl. Values obtained for saturated hydraulic conductivity in marl vary between $2.1 \times 10^{-6} \mathrm{~m} / \mathrm{sec}$ and $6.5 \times 10^{-7} \mathrm{~m} / \mathrm{sec}$. Thus the quantity of seepage to gully heads seems to be negligible and is probably not a significant variable for gully head migration. However variations in soil moisture content may be enough to cause the observed failures of the gully walls.

\section{CONCLUSIONS}

A methodology has been devised to examine the role of water in the development of gullies in south east Spain. Using a variety of standard and nonstandard field and laboratory techniques the important factors affecting gully erosion are being isolated and assessed. 


\section{CAROLYN FRANCIS}

\section{BIBLIOGRAPHY}

BLACK, C.A. (Ed.), 1965. Methods Of Soil Analysis. The American Society of Agronomy, Madison, Wisconsin, $1569 \mathrm{pp}$.

BRICE, J.C., 1966. Erosion and deposition in the loess-mantled Great Plains, Medicine Creek drainage basin, Nebraska. U.S.G.S. Professional Paper, 352-H, p255-339.

CAMPBELL G.S., 1974. A simple method for determining saturated conductivity from moisture retention data. Soil Science, 117(6), p311-314.

CAMPBELL, I.A., and J.L. HONSAKER, 1982. Variability in badlands erosion: problems of scale and threshold identification. Chapter 4 in Space And Time In Geomorphology, Ed. C.E. Thorn, (George Allan and Unwin, p.59-79.

FAULKNER, H., 1974. An allometric growth model for competitive gullies. Zeit. fur Gm. Suppl. Bd. 21, p76-87.

HILLS, R.C., 1970. The determination of the infiltration capacity of field soils using the cylinder infiltrometer. B.G.R.G. Technical Bulletin, No. 3, 25 pp.

HODGSON, J.M. (Ed.), 1976. Soil Survey Field Handbook: Describing And Sampling Soil Profiles. Soil Survey Technical Monograph, No. 5, (Harpenden), 99pp.

IMESON, A.C., F.J.P.M. KWAAD, and J.M. VERSTRATEN, 1982. The relationship of soil physical and chemical properties to the development of badlands in Morocco. Chapter 3 in Badlands Geomorphology And Piping, Eds. Bryan R. and A. Yair, (Geo Books), p47-70.

INSTITUTE OF HYDROLOGY, 1981. User's handbook for the Institute of Hydrology neutron probe system. Report No. 79, 30 pp.

IRELAND, H.A., C.F.S. SHARPE, and D.H. EARGLE, 1939. Principles of gully erosion in the Piedmont of South Carolina. U.S. Dept. of Agric. Tech. Bull. 63, 143 pp.

KIRKBY, M.J., 1980. The stream head as a significant geomorphic threshold. Chapter 4 in Thresholds In Geomorphology. Eds. Coates D.R. and S.D. Vitek, (George Allen and Unwin), p. 53-73.

PIEST, R.F. and BOWIE, A.J., 1974. Gully and streambank erosion. Proc. of the 29th Annual Meeting of the Soil Conservation Society of America, Syracuse, N.Y., p. 188-196.

SALES MARTINEZ, V., T. JAMBRINO CALVET, and J.J. JUSTE PEREZ, 1982. Análisis espacial y temporal de la sequia 1978-81 en España. Cuade. de Geogr., 30, Valencia, p. 13-24. 


\section{HYDROLOGICAL INVESTIGATIONS OF SOILS}

SCOGING, H.M., 1976. A stochastic model of daily rainfall simulation in a semiarid environment. Discussion Paper. London School of Economics and Political Science, Houghton Street, London, Noo. 59, 10 pp.

SCOGING, H.M., 1982. Spatial variations in infiltration, runoff and erosion on hillslopes in semi-arid Spain. Chapter 5 in Badland Geomorphology and Piping, Eds. Bryan R. and A. Yair, (Geo Books), p. 89-112.

SMITH, R.R., and F.P. BRETHERTON, 1972. Stability and the conservation of mass in drainage basin evolution. Water Resources Research, 8 p. 1506-24.

THORNES, J.B., 1976. Semiarid erosional systems: case studies from Spain. Geography Papers No. 7 London School of Economics and Political Science, Houghton Street, London, $79 \mathrm{pp}$.

WISE, S.M., J.B. THORNES, and A. GILMAN, 1982. How old are the badlands? A case study from south-east Spain. Chapter 14 in Badland Geomorphology and Piping, Eds. Bryan R. and A. Yair, (Geobooks), p. 259-277. 
